\title{
Pengaruh Pemberian Mulsa Jerami Padi dan Pupuk Kandang Ayam terhadap Produksi Bawang Merah (Allium cepa L. var. Ascalonicum)
}

\author{
Yosef Nong Baka, Yohanes Boli Tematan, Yohanes Nong Bunga \\ Program Studi Pendidikan Biologi, Fakultas Keguruan dan IImu Pendidikan, Universitas Nusa Nipa, \\ Maumere, 86111, Indonesia
}

Email: yohanestematan@gmail.com

\begin{abstract}
Abstrak. Pertumbuhan dan produksi bawang merah (Allium cepa L. var. Ascalonicum) sangat dipengaruhi oleh berbagai factor diantaranya pemberian pupuk dan mulsa. Perlakuan terhadap bawang merah (Allium cepa L. var. Ascalonicum) di Ihigetegera, Desa Watumilok, Kecamatan Kangae.dengan memberi mulsa jerami padi dan pukuk kadang ayam untuk mengetahui pertumbuhan dan proksinya. Metode pengambilan data dengan menggunakan rancangan acak kelompok faktorial dengan 3 ulangan dan 8 perlakuan, yaitu dua taraf mulsa jerami padi ( $M_{0}$ : tanpa mulsa dan $M:$ mulsa jerami padi), yang dikombinasikan dengan empat taraf dosis pupuk kandang ayam $\left(P_{0}\right.$ : tanpa pupuk, $P_{1}$ : pupuk $1 \mathrm{~kg}, \mathrm{P}_{2}$ : pupuk $2 \mathrm{~kg}$ dan $\mathrm{P}_{3}$ : pupuk $3 \mathrm{~kg}$ ). Parameter yang diamati adalah tinggi tanaman, jumlah individu baru, dan bobot basah umbi per sampel. Analisis data yang digunakan adalah analysis of variance (ANOVA) dengan taraf kepercayaan $5 \%(\alpha=0,05)$ yang dilanjutkan dengan uji Tukey dengan taraf signifikan $5 \%$ $(P=0,05)$. Hasil penelitian menunjukkan bahwa mulsa jerami padi berpengaruh nyata terhadap parameter tinggi tanaman, jumlah individu baru, dan bobot basah umbi per sampel. Pemberian pupuk kandang ayam berpengaruh nyata terhadap parameter tinggi tanaman, jumlah individu baru, dan bobot basah per sampel. Interaksi antara mulsa jerami padi dan pupuk kandang ayam berpengaruh nyata terhadap semua parameter pengamatan. Hasil terbaik dari penelitian ini diperoleh pada perlakuan mulsa jerami padi dengan pupuk $2 \mathrm{~kg}$.
\end{abstract}

Kata kunci: bawang merah; mulsa jerami padi; pupuk kandang ayam.

\section{Pendahuluan}

Bawang merah (Allium ascalonicum L.) merupakan salah satu komoditas hortikultura yang memiliki nilai ekonomi tinggi dan permintaan konsumsi terus meningkat namun belum diimbangi dengan peningkatan produksi. Rendahnya produktivitas bawang merah disebabkan oleh berbagai faktor, di antaranya tingkat serangan organisme penganggu tanaman yang tinggi, perubahan iklim mikro, penggunaan benih yang kurang bermutu dan aplikasi pemupukan yang tidak berimbang serta tingkat kesuburan tanah menurun karena kurangnya penggunaan pupuk organik.

Produksi bawang merah dapat mencapai hasil yang optimal apabila dalam sistem budidaya diperhatikan faktor-faktor yang dapat mempengaruhi pertumbuhannya. Faktor-faktor tersebut meliputi iklim, curah hujan, intensitas cahaya, ketinggian tempat, dan faktor tanah. Tanah yang baik untuk pertumbuhan bawang merah adalah kondisi tanah yang lembab karena bawang merah tidak tahan terhadap kekeringan. Pengaruh penyinaran matahari mengakibatkan ketersediaan 
air pada tanah menjadi lebih terbatas sehingga diperlukan usaha mencegah penguapan dengan pemberian mulsa.

Mulsa adalah bahan atau material yang digunakan untuk menutupi permukaan tanah atau lahan pertanian yang berfunsi untuk menekan pertumbuhan gulma, mempertahankan agregat tanah dari hantaman air hujan, memperkecil erosi permukaan tanah, mencegah penguapan air, melindungi tanah dari terpaan sinar matahari, dan dapat membantu memperbaiki sifat fisik tanah terutama struktur tanah sehingga memperbaiki stabilitas agregat tanah. Pemanfaatan mulsa diharapkan dapat membantu menurunkan laju infiltrasi (penguapan) dan porositas (penyerapan) air dalam tanah.

Faktor lain yang sangat berpengaruh terhadap pertumbuhan dan produksi bawang merah adalah kandungan unsur hara tanah.

Tanah yang mengandung unsur hara yang memadai dapat menunjang pertumbuhan dan produksi tanaman dengan baik Petani dalam upaya peningkatan produksi tanaman lebih memilih pupuk anorganik walaupun banyak efek negatif yang ditimbulkan. Bahan organik yang ada bisa

\section{Metode}

Penelitian dilaksanakan di Ihigetegera, Desa Watumilok, Kecamatan Kangae, Kabupaten Sikka pada bulan September sampai November 2018 dengan Rancangan Acak Kelompok Faktorial (RAKF) yang terdiri dari 2 faktor. Faktor pertama penggunaan mulsa $(\mathrm{M})$ terdiri dari dua taraf yaitu $M_{0}=$ tanpa mulsa dan $M=$ dengan mulsa jerami padi yang dikombiasikan dengan faktor kedua yaitu pupuk kandang ayam $(P)$ terdiri dimanfaatkan sebagai pupuk organik untuk memenuhi kebutuhan unsur hara tanaman. Pupuk organik memiliki keunggulan dibandingkan dengan pupuk anorganik. Keunggulan pupuk organik yaitu lebih ramah lingkungan dan aman jika diaplikasikan ke tanah. Pupuk organic bebas dari residu bahan kimia yang dapat merusak ekosistem tanah baik itu organisme tanah, air tanah, udara, dan dampaknya kepada manusia.

Pupuk kandang merupakan salah satu jenis pupuk organik yang dapat digunakan oleh petani. Pupuk kandang adalah pupuk yang berasal dari berbagai jenis kotoran hewan yang banyak mengandung unsur hara bagi tanaman baik itu unsur hara mikro maupun makro. Pupuk kandang yang bisa digunakan oleh petani yaitu pupuk kandang sapi, pupuk kandang ayam, pupuk kandang babi, pupuk kandang kambing dan berbagai jenis pupuk kandang lainnya.

Pemebrian pupuk kandang dapat memenuhi kebutuhan unsur hara tanaman dalam upaya peningkatan produksi. Pupuk kadang mudah diperoleh dan murah harganya namun belum dimanfaatkan secara maksimal.

dari empat taraf yaitu $P_{0}=$ tanpa pupuk kandang ayam, $P_{1}=10$ ton/ha atau setara dengan $1 \mathrm{~kg} /$ bedeng, $P_{2}=20$ ton/ha atau setara dengan $2 \mathrm{~kg} /$ bedeng, $P_{3}=30$ ton/ha atau setara dengan 3 $\mathrm{kg} / \mathrm{bedeng}$, sehingga terdapat 8 perlakuan.

Seluruh perlakuan diulang 3 kali sehingga terdapat 24 unit percobaan berukuran $1 \times 1 \mathrm{~m}$. Setiap unit percobaan ditanam 45 tanaman 
dengan jarak tanam $20 \times 10 \mathrm{~cm}$ sehingga populasi tanaman bawang merah sebanyak 1.080 tanaman. Setiap unit percobaan diambil secara acak 15 tanaman sehingga terdapat 360 tanaman sebagai sampel penelitian. Parameter yang diukur dalam penelitian ini adalah tinggi tanaman, jumlah individu baru per rumpun dan bobot basah per rumpun.

Model analisis data Rancangan Acak Kelompok (RAK) faktorial menurut Herdiyantoro (2013). Data yang diperoleh dianalisis menggunakan

\section{Hasil dan Pembahasan}

a. Tinggi tanaman

Kombinasi pemberian jenis mulsa dan pupuk kandang ayam memiliki pengaruh yang nyata $(\alpha<0,05)$. Tanaman bawang merah memiliki ratarata tertinggi pada kombinasi perlakuan $\mathrm{MP}_{2}$ dengan rata-rata $34,44 \mathrm{~cm}$, sedangkan rata-rata terendah terdapat rancangan acak kelompok faktorial (RAKF) dengan bantuan Minitab 16. Jika hasil uji ANOVA (Analisis of Variance) tidak berpengaruh (F hitung < $F$ tabel $5 \%$ ) tidak dilakukan uji lanjutan, sedangkan bila hasil sidik ragam berpengaruh ( $F$ hitung $>F$ tabel 5\%) atau berbeda sangat nyata ( $F$ hitung $>$ $F$ tabel 1\%), maka untuk membandingkan dua rata-rata perlakuan dilakukan uji lanjutan dengan uji Tukey taraf 5\% (Suntoyo Yitnosumarto, 1991).

pada kombinasi perlakuan $\mathrm{M}_{0} \mathrm{P}_{0}$ dengan rata-rata $25,30 \mathrm{~cm}, \mathrm{M}_{0} \mathrm{P}_{1}$ dengan ratarata $25,94 \mathrm{~cm}$, dan $\mathrm{M}_{0} \mathrm{P}_{3}$ dengan ratarata $27,14 \mathrm{~cm}$. Laju pertumbuhan tinggi tanaman bawang merah pada setiap perlakuan dapat digambarkan pada Gambar 1.

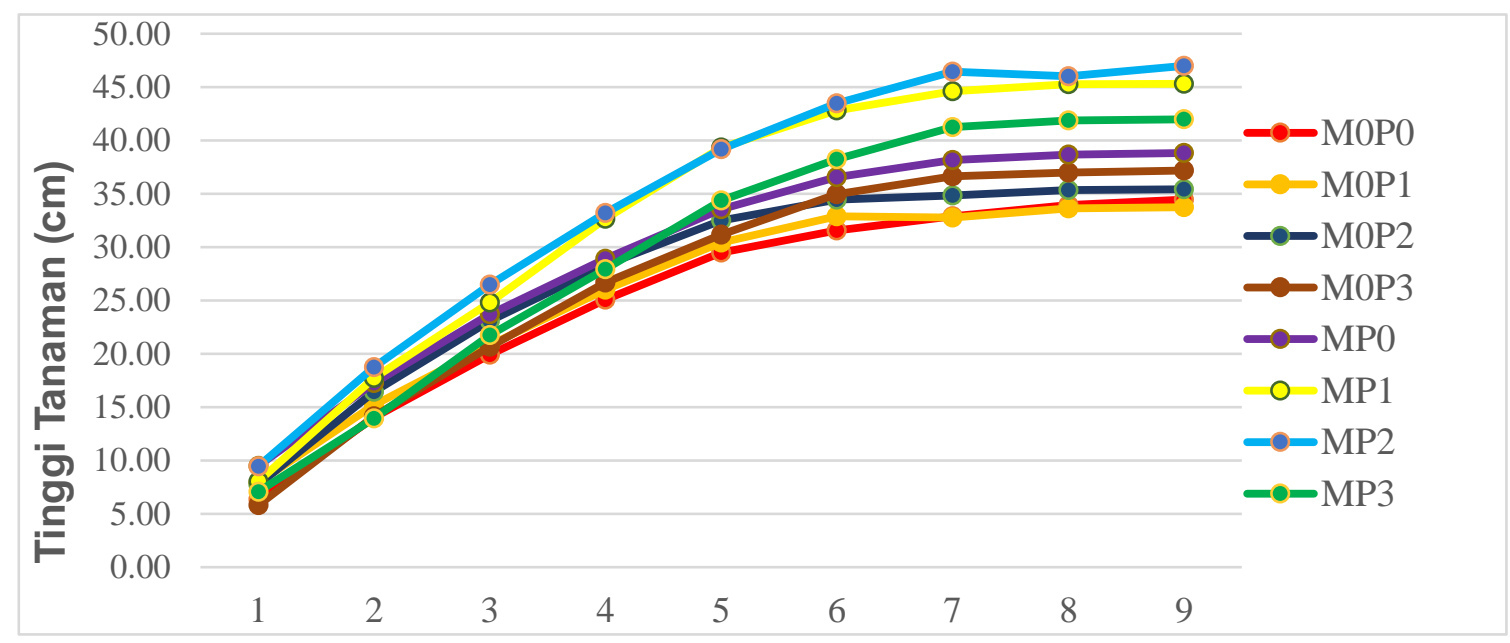

Gambar 1. Pertumbuhan tinggi tanaman bawang merah umur 1-9 mst $(\mathrm{cm})$

Pemberian pupuk kandang ayam dan mulsa jerami padi dapat meningkatkan laju pertumbuhan tanaman bawang merah. Mulsa jerami padi dapat mengurangi penguapan dan adanya unsur hara yang seimbang dengan memberikan pupuk kadang ayam dengan takaran $2 \mathrm{~kg}$ dapat merangsang pertumbuhan vegetatif tanaman. Kombinasi pemberian pupuk 
kandang ayam takaran $2 \mathrm{~kg}$ dengan mulsa jerami padi dapat memberikan hasil yang paling baik terhadap pertumbuhan tinggi tanaman bawang merah.

b. Jumlah individu baru

Jumlah individu baru tanaman bawang merah umur 1-9 mst dari masingmasing perlakuan secara umum setelah dilakukan uji ANOVA menunjukkan bahwa kombinasi pemberian jenis mulsa dan pupuk kandang ayam memiliki pengaruh yang nyata $(\alpha<$ 0,05). Tanaman bawang merah memiliki rata-rata jumlah individu baru tertinggi pada kombinasi perlakuan $\mathrm{MP}_{2}$ dengan rata-rata 6,012 , sedangkan rata-rata terendah terdapat pada kombinasi perlakuan $\mathrm{M}_{0} \mathrm{P}_{3}$ dengan nilai rata-rata 4,309. Rata-rata penambahan jumlah individu baru bawang merah dapat dilihat pada Gambar 2.

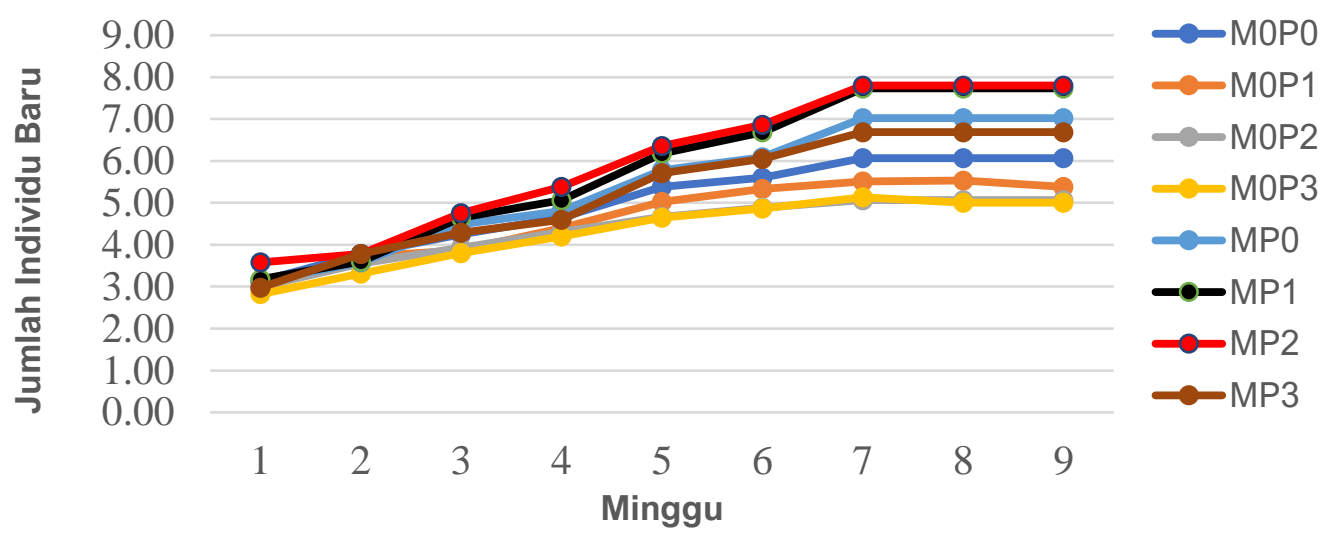

Gambar 2. Rata-rata Jumlah Individu Baru Umur 1-9 mst

Penambahan jumlah individu baru tanaman bawang merah pada perlakuan $\mathrm{MP}_{2}$, disebabkan karena adanya keseimbangan unsur hara yang terdapat dalam pupuk kandang ayam dan mulsa jerami padi. Peningkatan pertumbuhan dan produksi bawang merah disebabkan karena adanya penambahan unsur $\mathrm{N}$ yang berasal dari pupuk kandang ayam. Aplikasi $\mathrm{N}$ yang optimal dapat meningkatkan pertumbuhan tanaman, meningkatkan sintesis protein, pembentukan klorofil yang menyebabkan warna daun menjadi lebih hijau, dan meningkatkan rasio akar. Jumlah individu baru sangat mempengaruhi jumlah umbi pada tanaman. Semakin banyak jumlah individu baru, maka semakin banyak pula jumlah umbi yang dihasilkan. Ketersediaan nutrisi pada tanaman dapat mempengaruhi jumlah individu baru pada tanaman

Pupuk kandang ayam dengan takaran 3 $\mathrm{kg}$ memberikan hasil yang kurang baik karena unsur hara di dalam tanah terutama unsur $\mathrm{P}$ dan $\mathrm{K}$ sudah tinggi. Unsur kalium (K) juga mempunyai peranan penting bagi tanaman yaitu sebagai aktivator beberapa enzim dalam metabolisme, mempertahankan tekanan turgor sel dan kandungan air, meningkatkan ketahanan tanaman terhadap penyakit, kekeringan, 
memperbaiki hasil dan kualitas tanaman. Kelebihan unsur $\mathrm{K}$ menyebabkan tanaman kekurangan hara Mg yang berperan sebagai penyusun klorofil dan unsur $\mathrm{Ca}$ yang merupakan penyusun dinding sel dan pertumbuhan jaringan meristem.

pertumbuhan tanaman yang baik dapat tercapai apabila unsur hara yang dibutuhkan dalam pertumbuhan dan perkembangan berada dalam bentuk seimbang dan dalam konsentrasi yang optimum serta didukung oleh faktor lingkungannya. Modifikasi lingkungan dengan memberikan mulsa merupakan suatu cara memperbaiki tata udara tanah dan juga tersedianya air bagi tanaman. Pemberian mulsa dapat mempercepat pertumbuhan tanaman yang baru ditanam.

c. Bobot basah
Pemberian mulsa jerami padi dan pupuk kandang ayam dengan takaran yang berbeda memiliki pengaruh yang nyata $(\alpha<0,05)$ terhadap jumlah bobot basah tanaman bawang merah. Hasil pengamatan bobot basah pada tanaman bawang merah umur 65 hst dari masing-masing perlakuan secara umum setelah dilakukan uji ANOVA menunjukkan bahwa kombinasi pemberian jenis mulsa dengan pupuk kandang ayam pada tanaman bawang merah memiliki rata-rata berat bobot basah tertinggi pada kombinasi perlakuan $\left(\mathrm{MP}_{2}\right)$ dengan nilai rata-rata 192,2 g, dan rata-rata berat bobot basah terendah pada kombinasi perlakuan $\left(\mathrm{M}_{0} \mathrm{P}_{3}\right)$ dengan nilai rata-rata 103,3 g. Rata-rata bobot basah bawang merah dapat dilihat pada Gambar 3.

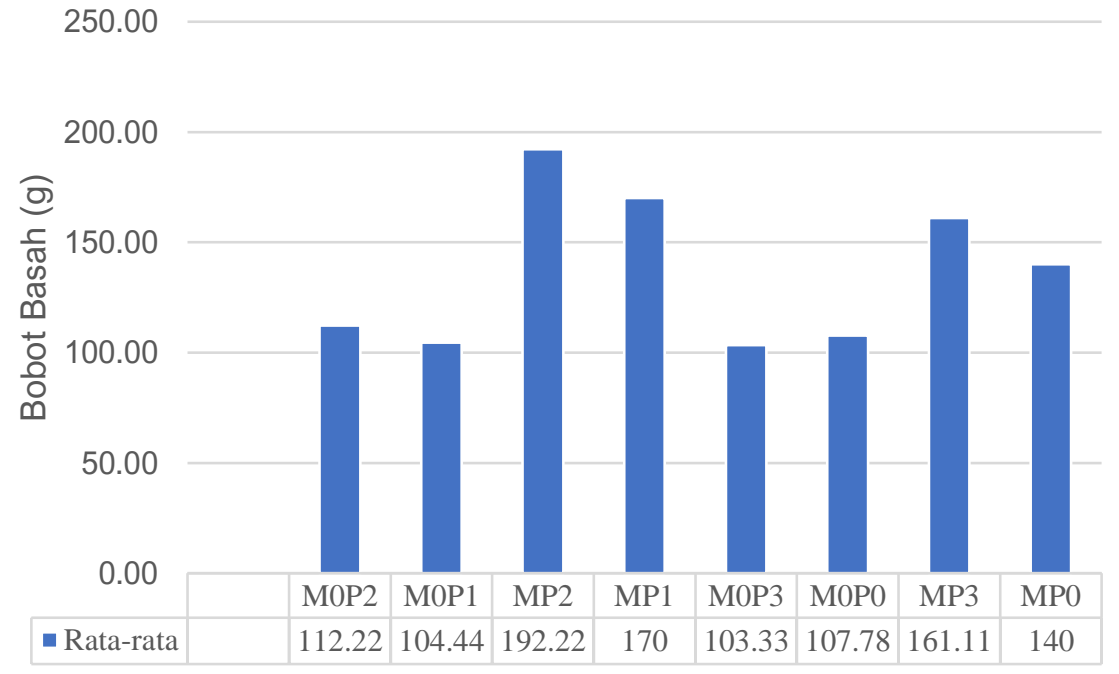

Gambar 3. Rata-rata bobot basah bawang merah

Berat basah tanaman bawang merah bertambah karena adanya keseimbangan unsur $\mathrm{N}$ dan $\mathrm{K}$ dalam pupuk kandang. Unsur nitrogen (N) yang diserap oleh tanaman akan menghasilkan asam nukleat yang terdapat di dalam inti sel. Asam nukleat berperan pada proses pembelahan sel sehingga terjadi perkembangan tanaman. Pembentukan lapisan-lapisan daun yang berkembang pada tanaman akan menjadi umbi bawang merah. 
Tersedianya unsur hara yang cukup memberikan respon positif terhadap pertumbuhan umbi. Unsur $\mathrm{N}$ diserap oleh tanaman selama masa pertumbuhan sampai dengan pematangan. Selain itu sumber kalium $(K)$ yang terdapat pada pupuk kandang juga berperan pada proses pembentukan umbi. Unsur $\mathrm{K}$ tersedia dalam keadaan cukup dapat memberikan pertumbuhan bawang merah lebih optimal dan menunjukan hasil yang baik. Kalium berpengaruh sangat nyata terhadap bobot basah per rumpun dan berperan dalam proses fotosintesis serta dapat meningkatkan berat umbi

\section{Kesimpulan}

Pertumbuhan dan produksi tanaman dapat meningkat apabila pengolahan tanah dilakukan dengan baik. Pemberian mulsa jerami padi dan pupuk kadang ayam merupakan salah satu alternatif pengolahan tanah yang berpengaruh nyata terhadap produksi bawang merah. Pertumbuhan dan produksi bawang merah lebih optimal pada kombinasi mulsa jerami padi dan pupuk kadang ayam dengan dosis $2 \mathrm{~kg}$.

\section{Daftar Pustaka}

1. Hartatik, W, dkk, Pupuk Kandang dan Pupuk Hayati. Bogor: Balai Besar Penelitian dan Pengembangan Sumberdaya Lahan Pertanian. 2006

2. Jazilah, S., Sunarto \& Farid, N. "Respon Tiga Varietas Bawang Merah Terhadap Dua Macam Pupuk Kandang dan Empat Dosis Pupuk Anorganik". Jurnal Penelitian dan Informasi Pertanian. 11 (1) 43 - 51. 2007.

3. Mas'ud, H., Yusuf, R \& Surajudin, A.. "Respon Tanaman Bawang Merah (Allium ascalonicum L.) Varietas Lembah Palu Terhadap Pemberian Jenis Mulsa dan Pupuk Organik Cair". e-J. Agrotekbis. 3(6) : 680 - 688. 2015

4. Novayana, D., Sipayung, R \& Barus, A. "Respons Pertumbuhan dan Produksi Bawang Merah (Allium ascalonicum L.) Terhadap Jenis Mulsa dan Pupuk Kandang Ayam". Jurnal Online Agroekoteknologi. 3 (2) : 446 - 457. 2015

5. Rahman, A. S., A. Nugroho \& R. Soeslistyono. "Kajian Hasil Bawang Merah (Allium ascalonicum L.) di Lahan dan Polybag dengan Pemberian Berbagai Macam dan Dosis Pupuk Organik." Jurnal Produksi Tanaman. 4 (7) : 538 - 546. 2016.

6. Rahayu, S., Elfarisna \& Rosdiana. "Respon Pertumbuhan dan Produksi Tanaman Bawang Merah (Allium ascalonicum L.) dengan Penambahan Pupuk Organik Cair". Jurusan Agroteknologi, Fakultas Pertanian, Universitas Muhammadiyah Jakarta. 2016.

7. Rukmana, H. R. \& Yudirachman, H. H. Sukses Budi Daya Bawang Merah di Pekarangan dan Perkebunan. Yogyakarta: Lily Publisher. 2017.

8. Setiawan., Susilo, B \& Tim Penulis ETOSA IPB.. Membuat Pupuk Kandang Secara Cepat. Jakarta: Penebar Swadaya. 2010 
9. Suharyanto \& Rinaldi, J. Estimasi Potensi dan Nilai Ekonomis Pupuk Kandang di Bali. Balai Pengkajian Teknologi Pertanian (BPTP), Bali. 2010.

10. Tandi, O.G., Paulus, J. \& Pinaria, A. "Pertumbuhan dan Produksi Bawang Merah (Allium ascalonicum L.) Berbasis Aplikasi Biourine Sap"i. Jurnal Eugenia. 21 (3) : 142 - 150. 2015.

11. Wulandari, W., Idwar \& Murniati. "Pengaruh Pupuk Organik dalam Mengefisenkan Pupuk Nitrogen untuk Pertumbuhan dan Produksi Tanaman Bawang Merah (Allium ascalonicum L.)." Jom Faperta 3 (2) : 1 - 13. 2016

12. Yartiwi \& Siagian, C. "Uji Dosis Pupuk Organik Cair Terhadap Pertumbuhan dan Hasil Bawang Merah. Prosiding Seminar Nasional Agroinovasi Spesifik Lokasi Untuk Ketahanan Pangan Pada Era Masyarakat Ekonomi ASEAN. Balai Pengkajian Teknologi Pertanian (BPTP) Bengkulu. 2014.

13. Yuliana., Rahmadani, E \& Permanasari, I." Aplikasi Pupuk Kandang Sapi dan Ayam Terhadap Pertumbuhan dan Hasil Tanaman Jahe (Zingiber Officinale Rosc.) di Media Gambut." Jurnal Agroteknologi. 5 (2) : 37 - 42. 2015.

14. Yusmalinda \& Ardian. Respon "Tanaman Bawang Merah (Allium ascalonicum L.) dengan Pemberian Beberapa Dosis Kompos Tandan Kosong Kelapa Sawit (TKKS)". JOM Faperta 4 (1) : 1.2017. 